May I finally add that, in the study of mineralogical equilibria, the practice of adding ferric iron and manganese to ferrous iron has no justification and can only bring confusion?

I am indebted to Dr. G. M. Brown for a stimulating discussion on pyroxene tie-lines.

\author{
UNIVERSTTÉ LOVANIUM, \\ LÉOPOLDVILLE, \\ RÉPUBLIQUE DU CONGO. \\ 13th February, 1961.
}

Paul Bartholomé.

\title{
REFERENCE
}

Mueller, R. F., 1960. Compositional characteristics and equilibrium relations in mineral assemblages of a metamorphosed iron formation. Amer. J. Sci., 258, 449-497.

\section{TERTIARY OF BARBADOS, W. I.}

SIR,- - In a recent paper on exploration results in Barbados, P. $\mathbf{H}$. Baadsgaard (1960) introduced several insufficiently defined stratigraphic terms that appear to offer no improvement on the definitions of A. Senn $(1940,1948)$.

Scotland Formation. Senn's Lower Scotland Formation includes the Morgan Lewis and the Walkers beds. Baadsgaard places his "P-unit" below the Walkers beds, and suggests the term "River Formation" for the three members. He describes his "P-unit" as " a new subsurface unit of black, sometimes fossiliferous silty shales and mudstones with few thin fine sandstones". Senn (1940, p. 1553) gave a thickness of 240 metres for the exposed type-section of the Walkers beds. In a bore-hole 650 metres of these beds were penetrated without having reached the bottom. The "P-unit" appears to form part of the lower, unexposed Walkers beds, hence the term "River Formation" appears to be unnecessary. If Baadsgaard wants to introduce a new subdivision he should bring out the lithological and palaeontological differences, and discuss the boundaries as seen in the Friendship well.

Senn's Upper Scotland Formation consists of Mount All, Chalky Mount, and Murphys beds. The "Bruce Vale Formation" of Baadsgaard embraces the same three members, and for this reason appears to be synonymous with Senn's Upper Scotland Formation.

Baadsgaard's "T-unit" is " a new subsurface stratigraphic element beneath the superficial Oceanic section in Friendship-1, Springvale-1, and Ince-1 ". This unit " consists of blue or purple claystones with thin siltstones and, locally, bedded sandstones and septarian limestones". In Text-fig. 2 the "T-unit" crosses the time lines from Middle Eocene to Upper Oligocene analogous to the older "P-unit". The "T-unit" of bore-hole Ince-1 is covered by beds of Baadsgaard's "Oceanic Group ", for which no age is given. Baadsgaard shows in his Text-fig. 3 at least " three superimposed major structural plates" which he assumes to be "sheet-like displacements with extensive overturned sections ". In none of the seven exploration wells is the "T-unit " involved in these tectonic complexities. It always rests on top of Senn's Scotland Formation, and below Baadsgaard's "Oceanic Group". Where palaeontologically identified in Ince-1, the "T-unit", Bruce Vale and River formations yielded faunas compared by Bronnimann with the Herrera member of the Cipero Formation of Trinidad. This makes them not older than Aquitanian and not "good Oligocene" as stated by Baardsgaard. Oceanic type marls are known from lower horizons of the Miocene, from Oligocene and from Eocene below which follows the Scotland Formation. Unless Baadsgaard can give strong proof of the highly diachronous nature of all these units it seems wiser to consider the younger, Miocene parts of the 
Bruce Vale and River formations, together with the "T-unit", as a flysch facies within younger formations and not as part of the Scotland Formation. An analogy could be drawn with Trinidad where the muddy flysch facies of the Nariva Formation interfingers with the Cipero marls.

Baadsgaard's term "Scotland Group" is premature as long as there are no well-defined formations to compose such a group.

Joes River Formation. Baadsgaard believes the Joes River Formation to be a kind of shear-zone breccia locally mobilized by gas, oil, and water, and occurring at different levels in his "Scotland Group". He is, therefore, not prepared to give the Joes River beds the rank of a formation. Senn considered the Joes River Formation to be the product of mud volcanoes, partly interbedded with normally deposited silts. To Hess $(1937$, p. 73 and 1938, p. 89) these rocks appeared "to be of the nature of a submarine landslide" which took place during the downward movement of the West Indian tectogene. The Joes River Formation of Senn is stratigraphically defined. Though shear zones may have given rise to the formation of " pebbly silts ", and are possibly responsible for the presence of large blocks of Paleocene Discocyclina limestone and other rocks, we must look upon the pebbly silt as representing mudflows separated one from the other by layers of normally bedded silt and clay. Senn $(1940$, p. 1576) considered the massive silt breccia and boulder beds to be resting with apparent unconformity on the Scotland beds. Baadsgaard found rocks of a lithology comparable to that of the Joes River Formation in Springvale-1 from 2,000 to 9,650 feet in the highly disturbed Scotland Formation. Senn (1940, p. 1574) already considered the Joes River pebbly silt to have been derived from various parts of the Scotland Formation, and to have ascended in vents that could now be interpreted as " mobilized shear zones ". The product of these shear zones could have been extruded, spread, and normally deposited as now found in the basal part of the Oceanic Formation. The pebbly silt is incompetent. Under orogenic pressure it was even injected into cracks of the Oceanic marls. Drilling in Trinidad has proved that Miocene pebbly clays with large blocks and slip-masses of pre-Miocene rocks form diapiroid bodies comparable to salt plugs. The writer saw no difference between the Joes River Formation and his "marineslope clay-breccias" (Kugler, 1953, p. 51) which he described from Trinidad. Marchant (1960), who described the Ancon "Clay Pebble-beds" of Ecuador, also studied those of Trinidad. He found both to be very similar sedimentary deposits, formed by submarine sliding. Baadsgaard (p. 24) states "... transitions can be traced from structureless Joes River to normal country rock" ; such transitions appear to exclude the presence of mobilized shear zones.

Oceanic Formation. Already Senn, and later Beckmann, have shown that the Oceanic Formation represents an uninterrupted sequence of foraminiferal marls with planktonic assemblages ranging in age from the middle Eocene Porticulasphaera mexicana zone to the top of the Codrington College marl, which belongs to the base of the Catapsydrax dissimilis zone of the Cipero Formation of Trinidad (Beckmann, 1956, p. 131). It is difficult to conceive how this uniformly widespread formation should be replaced by the Scotland Formation, or a facies of it, as is shown in Baadsgaard figure 2. The results of the bore-holes do not support his interpretation. No interdigitation of Oceanic type sediments with Scotland type sediments is known from surface exposures.

Bissex Hill Formation. This formation with its shallow water fauna overlaps the Oceanic Formation at Bissex Hill. It belongs to the Globigerinatella insueta zone and, in facies and age, is to be correlated with the Ste. Croix beds of Trinidad (Beckmann, 1956, p. 130). The Ste. Croix limestone is a member of the Cipero Formation with its calcareous clays and marls. In Trinidad deeper water Cipero marls were laid down contemporaneously with the Ste. Croix member, while in Barbados the lower part of the "Upper Oligocene Globigerina Marl " of Senn seems to be an age equivalent of the Bissex Hill Formation (according to Beckmann, 1956, p. 140). 
Upper Oligocene Globigerina Marl. Senn (1948, p. 214) described this marl in detail. He knew it only from water wells, but Beckmann (1956, p. 140) states : "The Upper Globigerina maris of Senn are now known from surface outcrops (e.g., at St. Mark's near Conset Bay). They represent the Globorotalia fohsi and Globigerinatella insueta zones. Therefore, they are not older than the Bissex Hill Formation, as Senn (1948) assumed, but younger." Finally Beckmann states: "The sedimentary facies of the "Upper Oligocene Globigerina marls' is closely related to that of the Codrington College member of the Oceanic formation." Baadsgaard gives no description of his "Waterwell Marls". There is little doubt, however, that they are the same as Senn's "Upper Oligocene Globigerina Marl ". It is here suggested that this marl be given the name " Conset Marl". Senn (1948, p. 215) believed that there are indications of an unconformity between his Upper Oligocene Globigerina Marl and his Oceanic Formation. According to Baadsgaard, exploration-well Adams Castle-1 penetrated 5093 feet of " an unbroken sequence from upper Eocene to upper Oligocene ". Apparently no "T-unit" or Bissex Hill Formation ws observed. The bore-hole proved the presence of a deep, post-middle Eocene trough that existed in the S.W. corner of Barbados. Should detailed palaeontological studies of the bore-hole samples corroborate Baadsgaard's claim, one would be justified in extending the term Oceanic Formation to include also marls of Miocene age. In such case one could treat the Bissex Hill Formation and the Conset Marl as members of the Oceanic Formation.

Acknowledgment. I am obliged to Mr. J. B. Saunders of Texaco Trinidad Inc., for contributions to this note.

Natural History MuSEUM, H. G. Kugler.

AUGUSTINERGASSE, Basel, SWITZERLAND.

22nd April, 1961 .

\section{REFERENCES}

BaAdsgaArd, P. H., 1960. Barbados, W. I. Exploration results, 1950-1958. Int. Geol. Congr. Report of 21 st Session, xviii, 21-27.

BeckmanN, J. P., 1956. Barbados. Léxique stratigraphic international. (Ámérique latine). Fasc. 2b. Antilles.

Hess, H. H., 1937. Geological interpretation of data collected on cruise of U.S.S. " Baracuda" in the West Indies. Trans. Am. Geoph. Union.

$\longrightarrow$, 1938. Gravity anomalies and island arc structure with particular reference to the West Indies. Proc. Amer. Phil. Soc., 79, No. 1.

Kugler, H. G., 1953. Jurassic to recent sedimentary environments in Trinidad. Bull. Ass. Suisse Géol. et Ing. Pet., 20, 27-60.

SenN, A., 1940. Paleogene of Barbados and its bearing on history and structure of Antillean-Caribbean Region. Bull. A.A.P.G., 24, No. 9.

1948. Die Geologie der Insel Barbados B.W.I. (kleine Antillen) und die Morphogenese der umliegenden Grossformen. Eclog. Geol. Helv. 40, No. 2. 